\title{
Disaster Mitigation in Physics Learning: Pedagogical Approach and Teaching Material Based on Higher Order Thinking Skills
}

\author{
Siska Desy Fatmaryanti ${ }^{1, *}$ Eko Setyadi Kurniawan ${ }^{1}$ Umi Pratiwi ${ }^{1}$ R Wakhid
}

Akhdinirwanto $^{1}$

\author{
${ }^{1}$ Department of Physics Education, Universitas Muhammadiyah Purworejo, Jl. KH Ahmad Dahlan 3 Purworejo \\ 54211, Indonesia \\ *Corresponding author. Email: siskadesy@umpwr.ac.id
}

\begin{abstract}
Public education about disaster mitigation in Indonesia needs to be done comprehensively. One of them is through learning at school. This study aims to integrate disaster mitigation in physics learning using a pedagogical approach and teaching materials based on higher-order thinking skills. This research is part of the development stage (R\&D), namely, the field test. The research subjects were 82 students from several high schools in Kebumen and Cilacap districts. Theoretical exploration, research instrument, and expert evaluation have been carried out based on higher-order thinking skills (HOTS) on the aspects of students' evaluation and analysis abilities. The data analysis technique is descriptive quantitative. The concept of wave propagation, momentum, and impulse raised in the integration of disaster mitigation can increase student HOTS. It found that the effectiveness of the pedagogic approach was included in the medium category ( $\mathrm{N}$-gain of 0.31 ). The use of teaching materials was also in the medium category ( $\mathrm{N}$-gain of 0.66 ). The results of this study can be used as a source of reference in teaching disaster mitigation in other physics concepts and other subjects in schools.
\end{abstract}

Keywords: Education, Physics Learning, HOTS.

\section{INTRODUCTION}

Indonesia's geographic location, which is located at the junction of three active plates, results in a high level of vulnerability to geological and hydro-climatological disasters [1], [2]. The National Disaster Management Agency (BNPB) recorded 2.127 natural disasters in Indonesia from 1 January to 22 September 2020. Kebumen and Cilacap are districts in Central Java, which are prone to earthquakes and tsunami. For this reason, an integrated effort is needed in reducing disaster risk.

Training for natural disaster preparedness has become a major concern of UNESCO. Under the "Decade of Education for Sustainable Development" (DESD), this training is intended for students to be able to protect themselves and behave appropriately if a disaster occurs [3]. Several studies found that disaster mitigation education should be part of the national curriculum. It applies to all levels of education from elementary to national secondary school by including in several school subjects, such as geography, social sciences, natural sciences, physics, history, and others. [3]-[5].

In the term learning and teaching process, innovative pedagogies are suggested. Teaching disaster mitigation in schools requires teachers to use active learning methods that are more relevant to their needs, interests, and able to motivate students to learn more. [3]. Pedagogical approaches must be active, interactive and participatory. The goal is for students to be able to turn on knowledge, practice skills and practice challenging attitudes. [6]. Knowledge needs to be internalized with contextualization in real situations. To reduce the risk of a disaster, increasing understanding through knowledge is essential. One way is by changing one's knowledge about something [7]. If students' knowledge about disasters is good, it will create a generation that is disaster resilient and has adequate disaster mitigation.

Bloom's Taxonomy can be classified into two levels, namely lower-order thinking (remember, understand, 
apply) and higher-order thinking (analyze, evaluate, create) [8]. This research focused on higher-order thinking skills (HOTS) in the term student's analyze and evaluate ability. There are three indicators in Analyze ability [9], [10], 1) Analyze incoming information and divide or structure information into smaller pieces to identify patterns or relationships; 2) Be able to identify and distinguish the causes and effects of a complicated scenario; 3) Identify/formulate questions. Evaluate ability has four indicators [10], [11], 1) Provide an assessment of solutions, ideas, and methodologies; 2) using suitable criteria or existing standards to ensure their effectiveness or usefulness; 3) Create hypotheses, criticize and perform tests; 4) Accept or reject a statement based on predetermined criteria.

The aim of this research 1) integrate disaster mitigation in physics learning using a pedagogical approach based on higher-order thinking skills; 2) integrate disaster mitigation in physics learning using teaching materials based on higher-order thinking skills; 3) Increase higher-order thinking skills student.

\section{METHOD}

This research is part of the development stage (R\&D), namely, the field test [12]. The research subjects were 82 students from several high schools in Kebumen and Cilacap districts. Theoretical exploration, research instrument and expert evaluation have been carried out based on HOTS on the aspects of students' evaluation and analysis abilities. The data analysis descriptive quantitative. The concept of wave propagation, momentum and impulse raised in the integration of disaster mitigation can increase student HOTS. To determine the level of effectiveness, we used the N-gain analysis obtained from the students' pre-test and post-test scores.

\section{RESULT AND DISCUSSION}

In our previous research, the learning design and learning media (modules) were obtained using the SETS (Science, Environment, Technology, Society) [13]. It has four steps in syntax, namely Invitation, Exploration, Solution, Application. The preparation of learning modules also uses disaster incident studies. For example, the collision material used a study of the earth's plate motion in an earthquake. The validation process has also been done before. Validation includes validation of media experts, learning models, and physics content.

The field test in this study was to determine the effectiveness of increasing student's HOTS. And from pre-test and post-test, $\mathrm{N}$-gain was found in the medium category for analysis and evaluation abilities. Figure 1 shown evaluation ability.

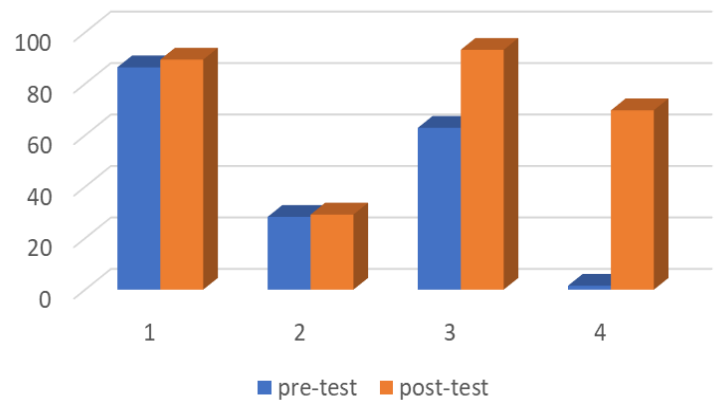

Figure 1 Evaluation ability

We can see from figure 1 that increasing has happened in every indicator. There is a significant increase in the 4th indicator, namely, accept or reject a statement based on predetermined criteria. In working on questions of this type, students can provide correct assessments and answers based on their requirements and understanding. For the next stage, students are asked to be able to make decisions and reasons why their answers are correct. What happens is that the reasons put forward are not by the prevailing concepts of physics and theory because students give reasons only based on observations and experiences that have been encountered in everyday events without thinking about what the physical concept is. It was in line with previous research mentioned another effect of direct observation; experiences can increasing students conception [14]. Figure 2 shows as analyze ability.

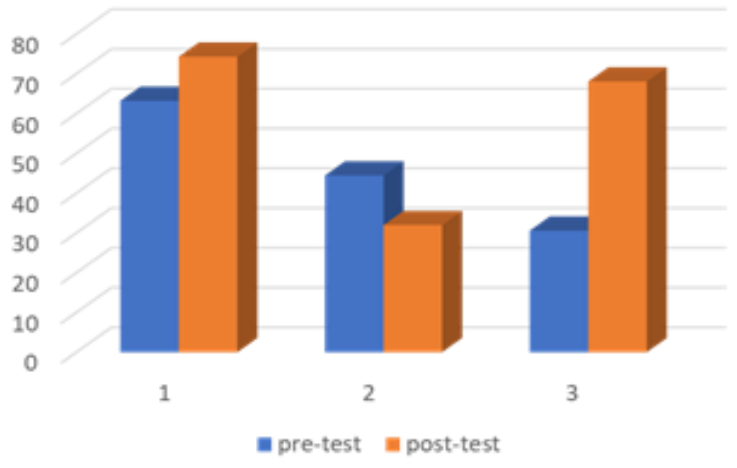

Figure 2 Analyze ability

A significant increase was found in the 3rd indicator, namely, identify/formulate questions. This indicator can be seen from the student's ability to connect the subject matter, keywords, viewpoints, or main concerns of a problem. The examples of the problems and the student's answers can be seen in Table 1. The questions in the exercises, assignments, and pre and post-tests used the approach of disaster events that recently occurred in Indonesia. Students were asked to perform analysis and evaluation by referring to the indicators above. 
Table 1. Example of problem and student's answer from the indicator of analysis ability

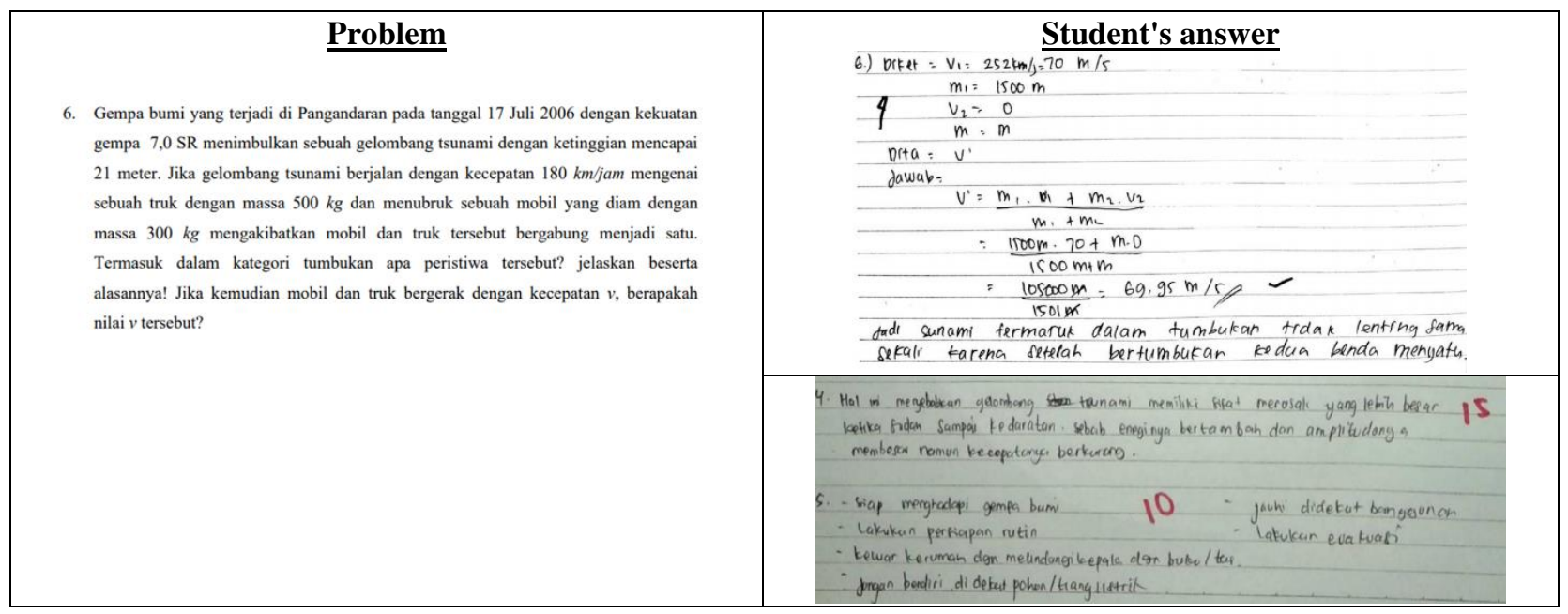

Judging from the results of the students' pre-test work for the collision material questions were not resilient at all associated with the earthquake disaster, all students still could not answer the questions. The results of the students' post-test work on the collision material questions were not resilient at all associated with the tsunami disaster, and the results showed that most of the students were able to answer these questions correctly and following the question commands. An example of students' answer is "the tsunami that hit dozens of houses and was washed away along with the water, including the collision, was not resilient at all because after the collision the two objects merged into one". From these answers, it can be seen that students can evaluate an event in a question associated with an earthquake or tsunami.

Each student has different basic abilities [8], [15]. Through the application of constructivism (SETS), students can learn from various starting points that they are familiar with the concepts of physics to be studied. In the learning process used can improve the way students think. This existence is evidenced by the activeness of students when expressing opinions in solving problems from natural disaster mitigation materials. Natural disaster mitigation materials are following the environment around students, both schools and residences. Learning materials are presented in the form of interactive modules so that learning is contextual. It plays an important role because the learning models and media used can train students' higher-order thinking skills [16]. HOTS can be formed when the learning process takes place, and the learning is student-centered [17]. In such a process, students are free to express their opinions according to the knowledge they have with contextual learning materials. What they often encounter natural disasters, there are even students who have experienced one of these natural disasters. So, the learning material used is very contextual and in accordance with the achievement strategy for the future.

\section{CONCLUSION}

From the results of this study, it can be concluded that Disaster mitigation can be integrated with physics learning by pedagogical approach and teaching material. And it can be effectively to increasing HOTS. The effectiveness of the pedagogic approach and teaching material was included in the medium category. And finally, as suggestions for future research, the results of this study can be used as a source of reference in teaching disaster mitigation in other physics concepts and other subjects in schools

\section{REFERENCES}

[1] R. Djalante and M. Garschagen, A Review of Disaster Trend and Disaster Risk Governance in Indonesia: 1900-2015. 2017.

[2] T. Lee, S. Fournier, A. L. Gordon, and J. Sprintall, "Maritime Continent water cycle regulates lowlatitude chokepoint of global ocean circulation," Nat. Commun., vol. 10, no. 1, pp. 1-13, 2019.

[3] D. Selby and F. Kagawa, Disaster risk reduction in school curricula: case studies from thirty countries. 2012.

[4] A. J. J. Auerbach and T. C. Andrews, "Pedagogical knowledge for active-learning instruction in large undergraduate biology courses: a large-scale qualitative investigation of instructor thinking," Int. J. STEM Educ., vol. 5, no. 1, 2018.

[5] M. R. Pahleviannur, "Edukasi Sadar Bencana Melalui Sosialisasi Kebencanaan Sebagai Upaya Peningkatan Pengetahuan Siswa Terhadap Mitigasi Bencana," J. Pendidik. Ilmu Sos., vol. 29, no. 1, pp. 49-55, 2019.

[6] S. P. Fraser, "Pedagogical Content Knowledge (PCK): Exploring its Usefulness for Science 
Lecturers in Higher Education," Res. Sci. Educ., vol. 46, no. 1, pp. 141-161, 2016.

[7] R. Arends, Learning to teach. McGraw-Hill Higher Education, 2014.

[8] L. O. Wilson, "Anderson and Krathwohl-Bloom's taxonomy revised," Underst. New Version Bloom. Taxon., 2016.

[9] Winarti, "Profil Kemampuan Berpikir Analisis Dan Evaluasi Mahasiswadalam Mengerjakan Soal Konsep Kalor," J. Inov. Dan Pembelajaran Fis., vol. 2, no. 1, pp. 19-24, 2015.

[10] P. K. Agarwal, "Retrieval practice \& Bloom's taxonomy: Do students need fact knowledge before higher order learning?," J. Educ. Psychol., vol. 111, no. 2, p. 189, 2019.

[11] G. Ramadhan, P. Dwijananti, and S. Wahyuni, "Analisis Kemampuan Berpikir Tingkat Tinggi (High Order Thinking Skills) Menggunakan Instrumen Two Tier Multiple Choice Materi Konsep Dan Fenomena Kuantum Siswa Sma Di Kabupaten Cilacap," Unnes Phys. Educ. J., vol. 7, no. 3, pp. 8590, 2018.

[12] M. Gall, J. Gall, and W. R. Borg, Educational research: An introduction, 8th ed. New york: Pearson Education, 2007.
[13] F. Y. Indrawati, S. D. Fatmaryanti, and A. Maftukhin, "Pengaruh Pembelajaran Fisika Menggunakan Model SETS (Science, Environment, Technology, and Society) Terintegrasi Mitigasi Bencana Alam Terhadap Kemampuan Analisis dan Transferable Skills Peserta Didik," Radiasi J. Berk. Pendidik. Fis., vol. 12, no. 2, pp. 54-60, 2019.

[14] S. D. Fatmaryanti, Suparmi, Sarwanto, and Ashadi, "Attainment of students' conception in magnetic fields by using of direct observation and symbolic language ability," in Journal of Physics Conference Series, 2017, vol. 909, no. 1, p. 12058.

[15] S. D. Fatmaryanti, Suparmi, Sarwanto, Ashadi, and H. Kurniawan, "Magnetic force learning with Guided Inquiry and Multiple Representations Model (GIMuR) to enhance students' mathematics modeling ability.," in Asia-Pacific Forum on Science Learning \& Teaching, 2018, vol. 19, no. 1.

[16] I. Z. Ichsan, D. V. Sigit, and M. Miarsyah, "Environmental learning based on higher order thinking skills: a needs assessment," Int. J. Educ. Vocat. Stud., vol. 1, no. 1, pp. 21-24, 2019.

[17] S. D. Fatmaryanti, Ashari, and V. S. Wahidah, "Students' representation based on high order thinking skills for the concept of light," in Journal of Physics Conference Series, 2020, vol. 1517, no. 1, p. 12056. 